\title{
A randomized controlled trial to assess the efficacy of tiotropium in Canadian patients with chronic obstructive pulmonary disease
}

\author{
Charles KN Chan MD ${ }^{1}$, François Maltais $\mathrm{MD}^{2}$, Chris Sigouin $\mathrm{MSc}^{3}$, Jennifer M Haddon MSc ${ }^{4}$, \\ Gordon T Ford MD ${ }^{5}$; on behalf of the SAFE Study Group
}

\begin{abstract}
CKN Chan, F Maltais, C Sigouin, JM Haddon, GT Ford. A randomized controlled trial to assess the efficacy of tiotropium in Canadian patients with chronic obstructive pulmonary disease. Can Respir J 2007;14(8):465-472.
\end{abstract}

BACKGROUND: Patients with chronic obstructive pulmonary disease (COPD) who smoke have a greater annual rate of decline in forced expiratory volume in $1 \mathrm{~s}\left(\mathrm{FEV}_{1}\right)$ than those patients who have stopped smoking.

OBJECTIVES: To assess the effect of tiotropium on pre-dose (trough) $\mathrm{FEV}_{1}$ in patients with COPD followed in Canada.

METHODS: A total of 913 patients were randomly assigned to receive either tiotropium $18 \mu \mathrm{g}$ once daily $(\mathrm{n}=608)$ or placebo (usual care minus inhaled anticholinergics) $(n=305)$ for 48 weeks in the present randomized, double-blind, parallel-group study. The effect of tiotropium on measurements of lung function $\left(\mathrm{FEV}_{1}, \mathrm{FEV}_{6}\right.$ and forced vital capacity), symptoms, health-related quality of life (St George's Respiratory Questionnaire) and exacerbations were examined.

RESULTS: Tiotropium improved trough $\mathrm{FEV}_{1}$ in both current and ex-smokers compared with placebo. Baseline $\mathrm{FEV}_{1}$ in smokers and ex-smokers was $1.03 \mathrm{~L}$ and $0.93 \mathrm{~L}$, respectively $(\mathrm{P}<0.001)$. At week 48, the mean difference between the tiotropium and placebo groups was $0.14 \pm 0.04 \mathrm{~L}(\mathrm{P}<0.001)$ in the smoker group and $0.08 \pm 0.02 \mathrm{~L}$ $(\mathrm{P}<0.0001)$ in the ex-smoker group. Tiotropium also significantly improved trough forced vital capacity and $\mathrm{FEV}_{6}$ compared with placebo throughout the treatment period $(\mathrm{P}<0.05$, for all). Furthermore, tiotropium significantly improved the St George's Respiratory Questionnaire total score compared with placebo at week 48 (40.9 versus 43.7 units, $\mathrm{P}<0.005$ ).

CONCLUSIONS: Compared with the placebo group, tiotropium provides sustained improvements in lung function in patients with COPD, with improvements for smokers and ex-smokers.

Key Words: COPD; Placebo; Randomized; Smoking; Tiotropium

Chronic obstructive pulmonary disease (COPD) is a major public health burden (1). It is currently ranked as the fourth leading cause of morbidity and mortality in Canada (2), and further increases in prevalence are predicted (3). Cigarette smoking is the major known risk factor for COPD. Cigarette smokers have a higher prevalence of respiratory symptoms and lung function abnormalities, a greater annual rate of decline in forced expiratory volume in $1 \mathrm{~s}\left(\mathrm{FEV}_{1}\right)$ and a greater $\mathrm{COPD}$ mortality rate than nonsmokers $(1,4,5)$. Smoking cessation is
Un essai aléatoire et contrôlé pour évaluer l'efficacité du tiotropium chez des patients canadiens atteints d'une maladie pulmonaire obstructive chronique

HISTORIQUE : Les patients atteints d'une maladie pulmonaire obstructive chronique (MPOC) qui fument présentent une diminution annuelle plus marquée de leur volume expiratoire par seconde (VEPS) que ceux qui ont arrêté de fumer.

OBJECTIFS : Évaluer l'effet du tiotropium sur le VEPS avant la prise de la dose (creux) chez des patients atteints d'une MPOC suivis au Canada. MÉTHODOLOGIE : Au total, 913 patients ont été divisés aléatoirement entre la prise de $18 \mu \mathrm{g}$ de tiotropium une fois par jour $(\mathrm{n}=608)$ ou d'un placebo (cas habituels déduction faite des anticholinergiques en aérosol; $\mathrm{n}=305$ ) pendant 48 semaines dans le cadre de la présente étude aléatoire à double insu en groupes parallèles. Les auteurs ont examiné l'effet du tiotropium sur les mesures de la fonction pulmonaire (VEPS, volume expiratoire en 6 secondes et capacité vitale forcée), des symptômes, de la qualité de vie reliée à la santé (questionnaire respiratoire de St. George) et des exacerbations.

RÉSULTATS : Par rapport au placebo, le tiotropium améliorait le creux du VEPS chez les fumeurs et les anciens fumeurs. Le VEPS de départ chez les fumeurs et les anciens fumeurs était de 1,03 L et de 0,93 L, respectivement $(\mathrm{P}<0,001)$. À la semaine 48 , la différence moyenne entre le groupe qui prenait du tiotropium et celui qui prenait un placebo était de $0,14 \pm 0,04 \mathrm{~L}(\mathrm{P}<0,001)$ dans le groupe des fumeurs et de $0,08 \pm 0,02 \mathrm{~L}$ $(\mathrm{P}<0,0001)$ dans le groupe d'anciens fumeurs. De plus, le tiotropium améliorait considérablement le creux de la capacité vitale forcée et du volume expiratoire en 6 secondes par rapport au placebo tout au long de la période de traitement ( $\mathrm{P}<0,05$ pour tous). Enfin, le tiotropium permettait d'accrôttre de manière significative l'indice total du questionnaire respiratoire de St. George par rapport au placebo lors de la semaine 48 (40,9 par rapport à 43,7 unités, $\mathrm{P}<0,005)$.

CONCLUSIONS : Par rapport au groupe sous placebo, les patients atteints d'une MPOC qui prenaient du tiotropium présentaient des améliorations soutenues de leur fonction pulmonaire, qu'ils soient fumeurs ou anciens fumeurs.

the only intervention that has been shown to reduce the rate of decline in $\mathrm{FEV}_{1}$ in patients with COPD (6). Smoking affects the response to corticosteroids in asthma, and smoking cessation may at least partially restore corticosteroid responsiveness in asthmatic ex-smokers (7). However, because tiotropium acts on the acetylcholine receptors rather than the steroid receptors, there may be a different effect and, hypothetically, smoking status may affect the response to tiotropium. From the results of the Lung Health Study (8), it appears that smoking

${ }^{1}$ University Health Network - Toronto General Hospital, Toronto, Ontario; ${ }^{2}$ Centre de recherche de l'Hôpital Laval, Institut universitaire de cardiologie et de pneumologie de l'Université Laval, Laval, Québec; ${ }^{3}$ University of Toronto, Department of Health Policy, Management and Evaluation, Toronto; ${ }^{4}$ Boehringer Ingelheim Canada Limited, Burlington, Ontario; ${ }^{5}$ Respiratory Division, University of Calgary, Calgary, Alberta

Correspondence and reprints: Dr Charles Chan, University Health Network - Toronto General Hospital, 585 University Avenue, Toronto, Ontario M5G 2N2. Telephone 416-340-3235, fax 416-971-6427, e-mail charles.chan@uhn.on.ca 
cessation is associated with an increase in bronchodilator response, so there may be a differential response to anticholinergic treatment in smokers and ex-smokers. Previous studies with tiotropium have documented smoking status before randomization but patients were not prospectively stratified to assess the potential interaction with treatment (9-14), hence the rationale to assess smoking status in this population.

Bronchodilators effectively control the symptoms of COPD and are currently the mainstay of treatment. Anticholinergic bronchodilators are one of the drug classes recommended by several international guidelines for first-line maintenance treatment of COPD $(1,15,16)$. Tiotropium is a once-daily anticholinergic bronchodilator that acts through prolonged $\mathrm{M}_{3}$-receptor blockade. One-year studies have demonstrated that tiotropium significantly improves lung function, reduces dyspnea and the incidence of exacerbations, and enhances health-related quality of life (HRQL) compared with either placebo or ipratropium $(9,10)$. Two six-month trials compared the bronchodilator efficacy of once-daily tiotropium with the twice-daily long-acting beta $_{2}$-agonist (LABA) salmeterol, and confirmed that tiotropium is effective in improving lung function and other clinical end points (12). As part of the continuing evaluation of tiotropium in Canada, it is important to assess the efficacy and safety of tiotropium in a Canadian health care setting. In addition, the current study was more reflective of standard Canadian pharmacotherapy for patients with moderate COPD (15) because the placebo group was allowed to remain on most of their respiratory medications except for the class of drug under study (anticholinergics).

The primary objective of the present trial was to assess the effect of tiotropium on $\mathrm{FEV}_{1}$ in patients with COPD. The effects of tiotropium in smokers and ex-smokers as well as its effect on various other patient-reported outcomes, including symptoms, HRQL and exacerbations, were also examined in the Canadian health care setting.

\section{PATIENTS AND METHODS}

\section{Study design}

The present study was a one-year, multicentre, randomized, double-blind, placebo-controlled, parallel-group study comparing the effect of tiotropium on morning pre-dose (ie, trough) $\mathrm{FEV}_{1}$ in patients with COPD. The trial (study protocol 205.259) was performed at 101 centres in Canada involving 72 specialists and 29 general practitioners. The study protocol was approved by the Therapeutic Products Directorate of Health Canada and an Institutional Review Board (local or central as required), and all participants gave written informed consent.

Screening assessments were made at visit 1 and, following a two-week run-in period, eligible patients were randomly assigned to receive either tiotropium $18 \mu \mathrm{g}$ once daily or placebo for 48 weeks (in a ratio of $2: 1$ ), delivered via the HandiHaler (Boehringer Ingelheim, Germany). The assessments made at visit 2 constituted the baseline values. The study was concluded with a two-week follow-up period. During the treatment period, patients were permitted oral corticosteroids (at a stable dose of $10 \mathrm{mg}$ or less of prednisone daily or equivalent), stable doses of inhaled corticosteroids, theophylline preparations, mucolytic preparations (not containing bronchodilators), LABAs and, for acute symptom relief, as-needed salbutamol metered-dose inhaler. Patients were not allowed to use inhaled anticholinergics (other than the study drug) or oral beta 2 -agonists during the treatment period. To treat COPD exacerbations during the trial, the investigators were permitted to administer any additional medication deemed necessary.

\section{Patients}

Male and female outpatients aged 40 years or older, with a clinical diagnosis of COPD $\left(\mathrm{FEV}_{1} 65 \%\right.$ predicted or less and $\mathrm{FEV}_{1} /$ forced vital capacity [FVC] $70 \%$ or less) (17) were considered for inclusion in the present study. Participants were required to have a smoking history of 10 pack-years or greater. The inclusion criteria relating to 'exacerbation history' initially required that patients had experienced one or more exacerbations within the past year (requiring treatment with antibiotics and/or oral steroids), but not within the six weeks before entering the study. However, due to slower than expected enrolment, this criterion was amended to include patients with fewer exacerbations (one exacerbation in the past two years).

Exclusion criteria were history of asthma, allergic rhinitis or atopy; a recent lower respiratory tract infection or any exacerbation (within the previous six weeks); a recent history of myocardial infarction (within the previous six months) or cardiac arrhythmia requiring drug therapy; and oral corticosteroid use at unstable doses during the six weeks before entering the study or at a stable dose exceeding the equivalent of $10 \mathrm{mg}$ prednisone daily. In addition, those patients with a significant disease other than COPD that would put the patient at risk because of participation in the study, or patients with a disease that may have influenced the results of the study, were not enrolled.

\section{Clinical assessments}

Spirometry was conducted in accordance with American Thoracic Society standards with office-based spirometry (18). The types of devices were not consistent but they were required to be American Thoracic Society approved. All spirometric tests were conducted in triplicate and the highest acceptable measurements were used in subsequent analyses. To ensure standardized conditions on spirometry test days, patients discontinued short-acting beta ${ }_{2}$-agonists $6 \mathrm{~h}$ before clinic visits, short-acting theophylline preparations $24 \mathrm{~h}$ before testing, and LABAs and long-acting theophylline preparations $48 \mathrm{~h}$ before testing.

The primary end point was morning pre-dose (trough) $\mathrm{FEV}_{1}$ at study end (48 weeks). Spirometry was conducted at screening and on day 1 of treatment (randomization) as well as after two, 11, 30 and 48 weeks of treatment. FEV $1, F V C$ and $\mathrm{FEV}_{6}$ (optional for qualified sites) were recorded $10 \mathrm{~min}$ before dosing (trough). Trough response was defined as the pre-dose value at each clinic visit after randomization, ie, $23 \mathrm{~h}$ to $24 \mathrm{~h}$ after the previous dose of trial medication.

HRQL was determined using the St George's Respiratory Questionnaire (SGRQ) before dosing on day 1 as well as after 30 and 48 weeks of treatment. The SGRQ is a validated 76-item questionnaire, split into three subscores - symptoms: assessing distress due to respiratory symptoms; activity: assessing the effects of breathlessness on mobility and physical activity; and impacts: assessing the psychosocial impact of disease. The SGRQ total score is a composite of all three subscores. Scores are weighted and range from 0 to 100 , with higher scores 
indicating a poorer HRQL. A difference of 4.0 or more units is considered clinically meaningful (19).

Detailed information on exacerbations and associated hospitalizations, and the number of courses of both oral steroids and antibiotics administered for the treatment of exacerbations were collected at each clinic visit. Data of health care use specifically related to COPD were collected on a separate page of the case report form. An exacerbation was defined as a complex of respiratory symptoms (new onset or an increase in at least one of cough, sputum, sputum purulence, dyspnea, wheeze, chest discomfort) lasting at least three days and requiring treatment with antibiotics and/or systemic steroids.

Adverse events were monitored throughout the treatment period.

\section{Statistical analysis}

Descriptive statistics (mean $\pm \mathrm{SD}$, and/or frequency, per cent) for patient characteristics at screening and adverse events are presented by treatment groups, tiotropium and placebo.

Change in $\mathrm{FEV}_{1}$, FVC, FEV 6 , SGRQ total score and subscores, and rescue medication use were compared between treatment groups, using an ANCOVA with the term treatment and baseline as a covariate. These analyses were applied to the full analysis set (FAS) patient population with the last observation carried forward method, except when patients discontinued because of worsening COPD, when the least favourable data before discontinuation were carried forward. The FAS population included all patients who were randomly assigned, took at least one dose of study medication, and had a valid baseline measurement and an additional measurement after at least one week of multiple dosing.

The number (per cent) of patients with at least one COPD exacerbation, and the number (per cent) of patients with at least one hospitalization due to a COPD exacerbation were each compared across treatment groups using the Fisher's exact test (two-sided). The number of COPD exacerbations, COPD exacerbation days, hospitalizations due to a COPD exacerbation, hospitalization days due to a COPD exacerbation and courses of steroids/antibiotics taken during a COPD exacerbation episode were each compared across treatment groups using Poisson regression with extent of exposure (minus the duration of events) as the offset. These analyses included patients who were randomly assigned and who took at least one dose of study medication.

As specified by the protocol, the planned analysis allowed for the stepwise further analysis of the difference in trough $\mathrm{FEV}_{1}$ at 48 weeks in the smoker and ex-smoker groups if a positive result was demonstrated in the treatment group comparison.

Univariate analyses, including one-way ANOVAs and Fisher's exact tests (two-sided), were applied to continuous and categorical variables, respectively, to compare smoker and ex-smoker patient characteristics at screening. These analyses included patients who were randomly assigned and who took at least one dose of study medication.

Within the smoker and ex-smoker groups, the change in $\mathrm{FEV}_{1}$ and the SGRQ total score were compared between treatment groups (tiotropium and placebo) using an ANCOVA with the term treatment and baseline as a covariate. The FAS was used in these analyses.

The SAS System for Windows version 8.2 (SAS Institute Inc, USA) was used to perform the analyses and a $\mathrm{P}<0.05$ was considered statistically significant.

\begin{tabular}{|c|c|c|c|}
\hline & Tiotropium & Placebo & Total \\
\hline Enrolled, $\mathrm{n}$ & & & 1294 \\
\hline Not entered, $\mathrm{n}$ & & & 381 \\
\hline Entered, $\mathrm{n}$ & 608 & 305 & 913 \\
\hline Treated, $\mathrm{n}(\%)$ & $608(100.0)$ & $305(100.0)$ & $913(100.0)$ \\
\hline Completed trial, $\mathrm{n}(\%)$ & $473(77.8)$ & $221(72.5)$ & $694(76.0)$ \\
\hline Prematurely discontinued, $\mathrm{n}(\%)$ & $135(22.2)$ & $84(27.5)$ & $219(24.0)$ \\
\hline Adverse events & $73(12.0)$ & $39(12.8)$ & $112(12.3)$ \\
\hline Administrative & $52(8.6)$ & $42(13.8)$ & $94(10.3)$ \\
\hline Other & $10(1.6)$ & $3(1.0)$ & $13(1.4)$ \\
\hline
\end{tabular}

One patient in the tiotropium treatment group did not take any study medication. *Patients received usual care minus anticholinergics

\section{Sample size}

A sample size of 900 patients (tiotropium: 600 patients; placebo: 300 patients) was estimated to provide $90 \%$ power to detect a between-group difference of $0.13 \mathrm{~L}$ in the primary end point ( $\mathrm{FEV}_{1}$ trough response) based on a standard deviation of $0.215 \mathrm{~L}$ at a $5 \%$ level of alpha confidence interval. The initial sample size calculation included three comparator groups: frequent smokers, infrequent smokers and ex-smokers. However, due to lower than expected recruitment, an amendment was created to reduce the number of comparator groups from three to two (smokers and ex-smokers).

\section{RESULTS}

A total of 913 patients were randomly assigned to one of two groups and treated, with 608 receiving tiotropium and 305 receiving placebo (Table 1 ). The two treatment groups were well matched at screening for demographics, disease characteristics and concomitant medication use (Table 2).

The patient characteristics at screening were compared between the smoker and ex-smoker groups. The ex-smokers were significantly older, and had a higher body mass index, lower values for lung function parameters and a lower SGRQ total score (Table 3).

More patients in the tiotropium group completed the trial than did those in the placebo group (77.8\% versus $72.5 \%)$, which created a potential bias. Additionally, at day 50 of treatment, the discontinuation rate was higher in the placebo group $(12.5 \%)$ than in the tiotropium group $(7.4 \%)$. This resulted in an exposure difference to treatment, with the mean difference between tiotropium and placebo groups being 19 days. The characteristics of the drop outs at baseline suggest that these patients had more severe COPD; they had lower lung function, greater use of respiratory medications and almost double the use of oxygen therapy compared with the study completers (Table 4).

\section{Spirometry}

Patients in the tiotropium group showed a statistically significant increase in trough $\mathrm{FEV}_{1}$ compared with the placebo group at week 48 (1.07 L versus $0.97 \mathrm{~L}$; mean $( \pm \mathrm{SE})$ difference: $0.10 \pm 0.02 \mathrm{~L}$; $\mathrm{P}<0.0001)$. A statistically significant mean difference of $0.10 \mathrm{~L}$ was first seen after two weeks of multiple dosing and was maintained throughout the trial $(\mathrm{P}<0.0001)$ (Figure 1A).

In addition, within both the smoker and ex-smoker groups, the tiotropium group showed a statistically significant increase 
TABLE 2

Patient characteristics at screening by treatment group

\begin{tabular}{|c|c|c|}
\hline & Tiotropium & Placebo \\
\hline Total randomized, $\mathrm{n}$ & 608 & 305 \\
\hline Male, \% & 59 & 61 \\
\hline Age, years & $66.8 \pm 8.7$ & $66.9 \pm 9.1$ \\
\hline Duration of COPD, years & $9.9 \pm 8.1$ & $9.9 \pm 7.9$ \\
\hline Smoking history, pack-years & $50.2 \pm 22.6$ & $51.0 \pm 26.3$ \\
\hline Current smoker, \% & 32 & 30 \\
\hline $\mathrm{FEV}_{1}, \mathrm{~L}$ & $0.97 \pm 0.39$ & $0.96 \pm 0.38$ \\
\hline $\mathrm{FEV}_{1}, \%$ predicted & $39.4 \pm 13.4$ & $39.3 \pm 13.6$ \\
\hline FVC, L & $2.11 \pm 0.76$ & $2.11 \pm 0.73$ \\
\hline $\mathrm{FEV}_{6}, \mathrm{~L}^{*}$ & $1.92 \pm 0.62$ & $1.97 \pm 0.59$ \\
\hline $\mathrm{FEV}_{1} / \mathrm{FVC}, \%$ & $46.4 \pm 11.6$ & $46.3 \pm 11.8$ \\
\hline \multicolumn{3}{|l|}{ Respiratory medication use, $\mathrm{n}(\%)$} \\
\hline Any pulmonary medication & $525(86.3)$ & $278(91.1)$ \\
\hline Anticholinergic & $359(59.0)$ & $185(60.7)$ \\
\hline Beta $_{2}$-agonist, oral & $1(0.2)$ & $0(0.0)$ \\
\hline Short-acting beta ${ }_{2}$-agonist, inhaled & $389(64.0)$ & $213(69.8)$ \\
\hline Long-acting beta $_{2}$-agonist, inhaled & $330(54.3)$ & $161(52.8)$ \\
\hline Leukotriene receptor antagonist & $5(0.8)$ & $7(2.3)$ \\
\hline Theophyllines & $64(10.5)$ & $26(8.5)$ \\
\hline Steroids, inhaled & $400(65.8)$ & $217(71.1)$ \\
\hline Steroids, oral & $23(3.8)$ & $11(3.6)$ \\
\hline Oxygen & $39(6.4)$ & $27(8.9)$ \\
\hline
\end{tabular}

Data are presented as mean $\pm S D$ unless otherwise indicated. ${ }^{*}$ Forced expiratory volume in $6 s\left(F E V_{6}\right)$ was only measured at qualified sites, and includes 79 patients in the tiotropium group and 40 patients in the placebo group. COPD Chronic obstructive pulmonary disease; FEV 1 Forced expiratory volume in $1 \mathrm{~s}$; FVC Forced vital capacity

\section{TABLE 3}

Patient characteristics at screening: Smoker versus ex-smoker

\begin{tabular}{lccr}
\hline & Smoker & Ex-smoker & $\mathbf{P}$ \\
\hline Total randomized, $\mathrm{n}$ & 287 & 626 & \\
Male, \% & 52.3 & 63.3 & 0.0018 \\
Age, years & $63.3 \pm 8.8$ & $68.4 \pm 8.3$ & $<0.0001$ \\
Body mass index, kg/m² & $26.07 \pm 6.17$ & $27.14 \pm 5.81$ & 0.0113 \\
Duration of COPD, years & $9.5 \pm 8.0$ & $10.1 \pm 8.1$ & $\mathrm{NSD}$ \\
Smoking history, pack-years $^{2}$ & $47.9 \pm 22.1$ & $51.6 \pm 24.6$ & 0.0300 \\
FEV $_{1}, \mathrm{~L}$ & $1.03 \pm 0.41$ & $0.93 \pm 0.37$ & 0.0003 \\
FEV $_{1}, \%$ predicted & $41.4 \pm 13.4$ & $38.4 \pm 13.4$ & 0.0016 \\
FVC, L & $2.12 \pm 0.77$ & $2.11 \pm 0.74$ & $\mathrm{NSD}$ \\
FEV $_{6}$, L $^{*}$ & $2.13 \pm 0.72$ & $1.86 \pm 0.54$ & 0.0270 \\
FEV $_{1} / \mathrm{FVC}, \%$ & $49.4 \pm 10.9$ & $44.9 \pm 11.7$ & $<0.0001$ \\
SGRQ total score $^{\dagger}$ & $49.1 \pm 17.2$ & $46.5 \pm 16.7$ & 0.0339 \\
\hline
\end{tabular}

Data are presented as mean $\pm S D$ unless otherwise indicated. *Forced expiratory volume in $6 s\left(F E V_{6}\right)$ was only measured at qualified sites, and includes 34 smokers and 85 ex-smokers; ' ${ }^{+}$Means from baseline assessment. COPD Chronic obstructive pulmonary disease; FEV 1 Forced expiratory volume in $1 \mathrm{~s}$; FVC Forced vital capacity; NSD No significant difference; SGRQ St George's Respiratory Questionnaire

in trough $\mathrm{FEV}_{1}$ (Figure 1B [smokers] and Figure 1C [ex-smokers]) when compared with placebo. Smokers had a greater (11.5\%) improvement in per cent change in $\mathrm{FEV}_{1}$ from baseline compared with ex-smokers (7.0\%). At study end (week $48)$, the mean difference $( \pm$ SE) between the tiotropium and
TABLE 4

Patient characteristics at screening

\begin{tabular}{|c|c|c|c|}
\hline & Completers & Drop outs & $\mathbf{P}$ \\
\hline Total randomized, $\mathrm{n}$ & 694 & 219 & \\
\hline Male, \% & 61 & 57 & 0.3444 \\
\hline Age, years & $66.3 \pm 8.8$ & $68.4 \pm 8.7$ & 0.0028 \\
\hline Duration of COPD, years & $9.8 \pm 8.2$ & $10.3 \pm 7.5$ & 0.4827 \\
\hline Smoking history, pack-years & $49.3 \pm 23.2$ & $54.0 \pm 25.7$ & 0.0108 \\
\hline Current smoker, \% & 33 & 26 & 0.0367 \\
\hline $\mathrm{FEV}_{1}, \mathrm{~L}$ & $0.99 \pm 0.38$ & $0.86 \pm 0.37$ & $<0.0001$ \\
\hline $\mathrm{FEV}_{1}, \%$ predicted & $40.2 \pm 13.3$ & $36.5 \pm 13.7$ & 0.0004 \\
\hline FVC, L & $2.16 \pm 0.74$ & $1.96 \pm 0.74$ & 0.0004 \\
\hline $\mathrm{FEV}_{6}, \mathrm{~L}^{*}$ & $2.02 \pm 0.61$ & $1.59 \pm 0.48$ & 0.0015 \\
\hline $\mathrm{FEV}_{1} / \mathrm{FVC}, \%$ & $46.8 \pm 11.6$ & $44.7 \pm 11.8$ & 0.0180 \\
\hline \multicolumn{4}{|l|}{ Respiratory medication use, $\mathrm{n}(\%)$} \\
\hline Any pulmonary medication & $602(86.7)$ & $201(91.8)$ & 0.0561 \\
\hline Anticholinergic & $387(55.8)$ & $157(71.7)$ & $<0.0001$ \\
\hline Beta $_{2}$-agonist, oral & $1(0.1)$ & $0(0.0)$ & 1.0000 \\
\hline Short-acting beta $_{2}$-agonist, inhaled & $444(64.0)$ & $158(72.1)$ & 0.0273 \\
\hline Long-acting beta $_{2}$-agonist, inhaled & $361(52.0)$ & $130(59.4)$ & 0.0622 \\
\hline Leukotriene receptor antagonist & $5(0.7)$ & $7(3.2)$ & 0.0108 \\
\hline Theophyllines & $59(8.5)$ & $31(14.2)$ & 0.0188 \\
\hline Steroids, inhaled & $454(65.4)$ & $163(74.4)$ & 0.0131 \\
\hline Steroids, oral & $16(2.3)$ & $18(8.2)$ & 0.0003 \\
\hline Oxygen & $42(6.1)$ & $24(11.0)$ & 0.0237 \\
\hline
\end{tabular}

Data are presented as mean $\pm S D$ unless otherwise indicated. *Forced expiratory volume in $6 s$ ( $F E V$ ) was only measured at qualified sites, and includes 95 completers and 24 drop outs. COPD Chronic obstructive pulmonary disease; FEV 1 Forced expiratory volume in $1 \mathrm{~s}$; FVC Forced vital capacity

placebo treatment groups was $0.14 \pm 0.04 \mathrm{~L}(\mathrm{P}<0.001)$ in the smoker group and $0.08 \pm 0.02 \mathrm{~L}(\mathrm{P}<0.0001)$ in the ex-smoker group, and the difference between the groups was statistically significant $(\mathrm{P}=0.01)$.

Tiotropium significantly increased trough FVC and $\mathrm{FEV}_{6}$ throughout the trial when compared with placebo. At week 48 , the mean difference $( \pm \mathrm{SE})$ between the treatment groups was $0.18 \pm 0.04 \mathrm{~L}(\mathrm{P}<0.0001)$ and $0.13 \pm 0.05 \mathrm{~L}(\mathrm{P}<0.05)$ for $\mathrm{FVC}$ and $\mathrm{FEV}_{6}$, respectively.

\section{HRQL}

Tiotropium significantly improved the SGRQ symptom score $(44.4$ versus $49.3, \mathrm{P}<0.01)$, impact score $(28.5$ versus 31.3, $\mathrm{P}<0.01)$ and total score $(40.9$ versus $43.7, \mathrm{P}<0.01)$ when compared with placebo at week 48 (Figure 2A). At week $48,53 \%$ of patients in the tiotropium group had clinically meaningful improvements from baseline (4.0 units or greater improvement) in SGRQ total scores compared with $44 \%$ of patients in the placebo group $(\mathrm{P}=0.052$, CochranArmitage two-sided trend test). Despite a significant difference at screening between the SGRQ score for smokers and ex-smokers (Table 3), treatment with tiotropium for smokers and ex-smokers resulted in greater improvements in the SGRQ total score when compared with the placebo group, 4.2 units and 2.0 units (Figure 2B).

Rescue medication

Patients receiving tiotropium self-administered approximately six fewer puffs of rescue medication per week compared with 


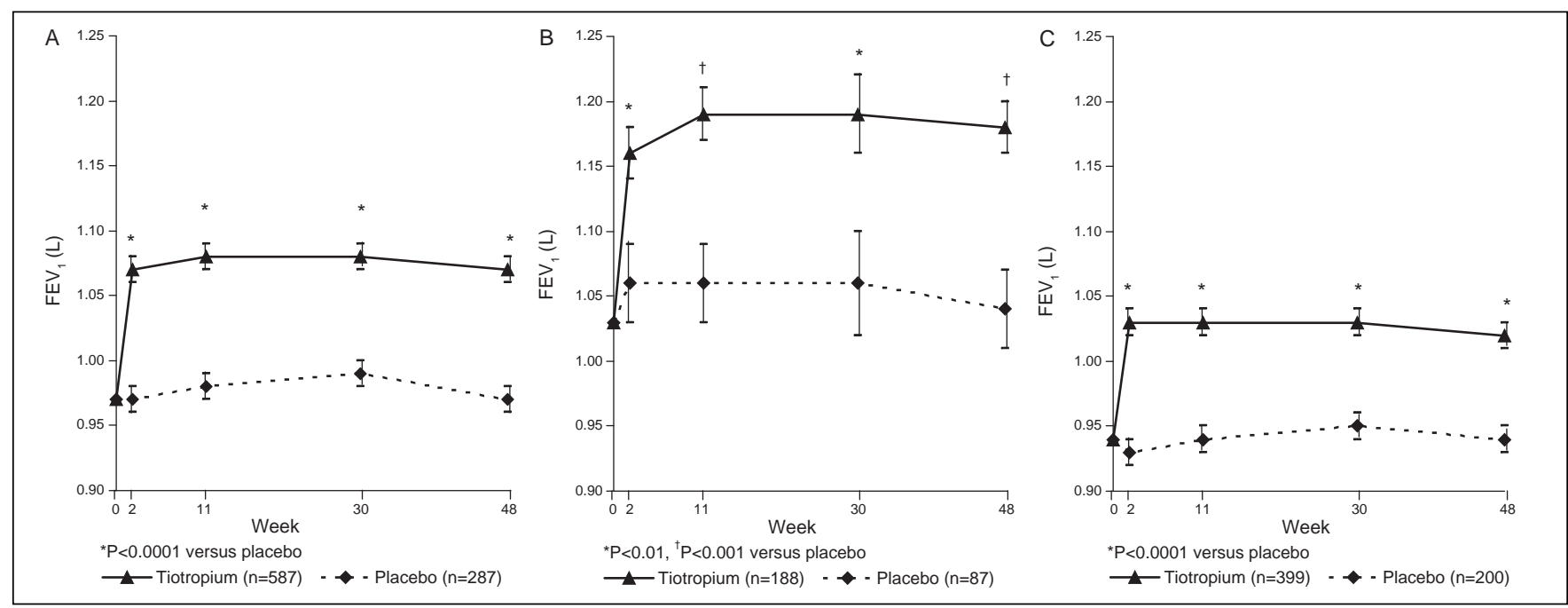

Figure 1) Mean trough forced expiratory volume in $1 \mathrm{~s}\left(\mathrm{FEV}_{1}\right)$ at baseline and at weeks 2, 11, 30 and 48 in all patients (A), smokers (B) and ex-smokers $(\mathrm{C})$. Adjusted means $\pm \mathrm{SE}$ are shown

those in the placebo group $(\mathrm{P}<0.01$, at all time points), which was first observed at week 1 and was maintained throughout the 48-week treatment period.

\section{Exacerbations and associated health care utilization}

The percentage of patients with at least one COPD exacerbation and the percentage of patients with at least one hospitalization due to a COPD exacerbation did not differ between treatment groups (Table 5). The number of COPD exacerbations per patient-year (adjusted for exposure) on treatment in the tiotropium group was 0.88 compared with 0.92 in the placebo group $(\mathrm{P}=0.599)$, and the number of COPD exacerbation days per patient year was 16.13 days in the tiotropium group compared with 16.19 days in the placebo group $(\mathrm{P}=0.843)$. Similarly, both the number of hospitalizations and the number of hospitalization days due to a COPD exacerbation did not differ between the two treatment groups (Table 5). There was also no difference between the treatment groups in the number of courses of oral steroids or antibiotics for the treatment of COPD exacerbations (Table 5).

\section{Adverse events}

The proportion of patients experiencing a treatment-emergent adverse event over the course of the one-year study was similar in both the tiotropium (78.9\%) and placebo (74.1\%) groups. The proportion of patients experiencing an adverse event leading to discontinuation was $11.5 \%$ and $12.1 \%$ in the tiotropium and placebo groups, respectively. Dry mouth occurred in $3.5 \%$ of patients in the tiotropium group and $3.6 \%$ of patients in the placebo group. Overall, $17 \%$ of the patients reported a treatment-emergent serious adverse event, with $18.4 \%$ in tiotropium group compared with $14.1 \%$ in the placebo group. There were 15 fatalities (13 [2.1\%] in the tiotropium group and two $[0.7 \%]$ in the placebo group) during the treatment period and four fatalities during the post-trial period (two [0.3\%] in the tiotropium group and two [0.7\%] in the placebo group).

\section{DISCUSSION}

Large clinical trials for drug registration of tiotropium were performed in multiple countries outside of Canada and at clinical research centres. As part of an ongoing postapproval program, the current trial investigated tiotropium in a Canadian health care setting. The trial confirmed that tiotropium is effective at improving lung function in both current smokers and ex-smokers, even with the placebo group already receiving most elements of usual care.

There was some speculation that current smoking may affect the response to tiotropium, as is seen in previous studies with corticosteroid treatment in asthma (7) and bronchodilator treatment in COPD (8), but this was not observed in the current study. This may be due to the substantial differences between the smoker and ex-smoker subgroups, and it would have been better to stratify the patients before randomization to ensure balanced groups. Smoking status was recorded at screening but was not confirmed at study completion by either asking the patient or by measuring serum cotinine levels. This study does show, however, that regardless of ongoing physician attempts to promote smoking cessation, the approximately $100 \mathrm{~mL}$ or $10 \%$ improvement in lung function with tiotropium in patients already receiving the benefits of usual care will still be realized.

Baseline trough $\mathrm{FEV}_{1}$ and absolute $\mathrm{FEV}_{1}$ were lower in exsmokers compared with smokers. This may have been due to a form of selection bias in that more severe patients may be more committed to smoking cessation.

The smaller gain in $\mathrm{FEV}_{1}$ with tiotropium in ex-smokers could be attributed to greater disease severity and therefore to less potential for reversibility compared with current smokers. However, this hypothesis has been refuted by Calverley et al (20), who found that baseline lung function (with $\mathrm{FEV}_{1}$ ranging from $0.5 \mathrm{~L}$ to $2.0 \mathrm{~L}$ ) does not influence the absolute improvement in $\mathrm{FEV}_{1}$ following bronchodilation. Although matching smokers and nonsmokers for disease severity would have been preferable, we believe that the observation that tiotropium is effective in current smokers is valid.

In previous tiotropium studies $(9,10)$, the improvement in $\mathrm{FEV}_{1}$ was $120 \mathrm{~mL}$ to $150 \mathrm{~mL}$ compared with placebo or ipratropium. The mean improvement in $\mathrm{FEV}_{1}$ of approximately $100 \mathrm{~mL}$ observed in the present study may reflect the fact that patients in the placebo group were allowed to take LABAs, which were usually excluded in previous studies. In one recent 


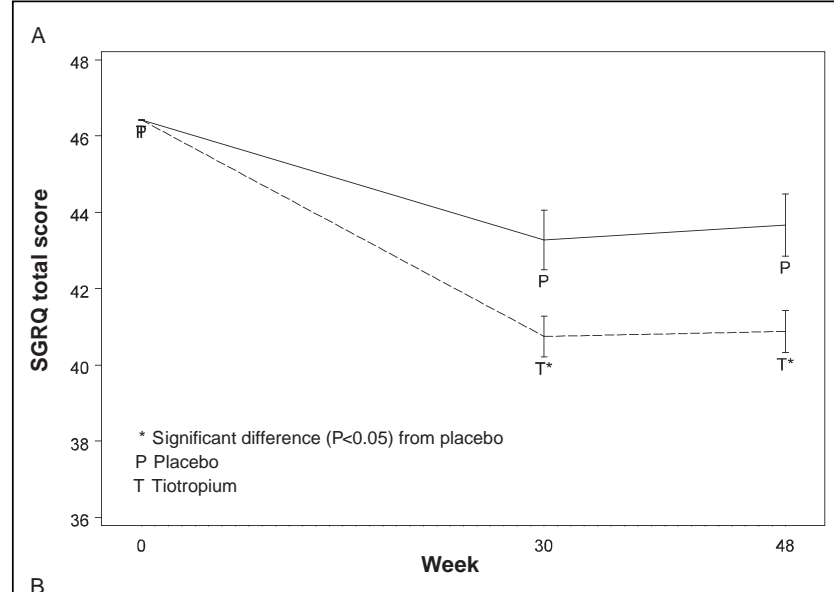

B
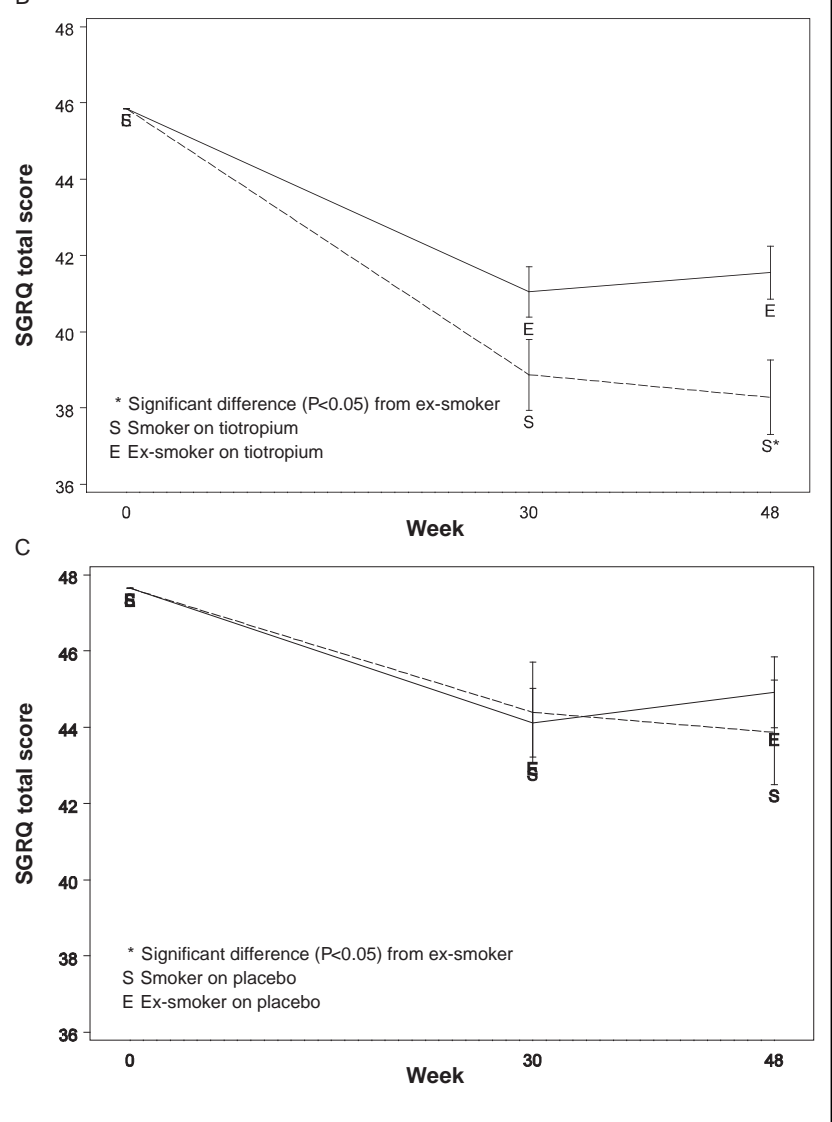

Figure 2) St George's Respiratory Questionnaire (SGRQ) total score over 48 weeks for the tiotropium and placebo groups, and according to smoking status for tiotropium and placebo groups. A SGRQ total score over 48 weeks for tiotropium and placebo groups; B Tiotropium, smoking status and SGRQ total score over 48 weeks; C Placebo, smoking status and SGRQ total score over 48 weeks

study by Niewoehner et al (13), which did permit the concomitant use of LABAs, the difference in trough $\mathrm{FEV}_{1}$ between tiotropium and placebo was also $100 \mathrm{~mL}$. The difference between the groups might have been larger if there had been fewer drop outs of sicker patients in the placebo group.

FVC and $\mathrm{FEV}_{6}$ (secondary end points) also improved with tiotropium compared with the placebo group. Again, the mean improvement in FVC $(180 \mathrm{~mL})$ was slightly less than the $210 \mathrm{~mL}$ to $290 \mathrm{~mL}$ improvement found in the
TABLE 5

Impact of treatment on exacerbations and health care utilization during the study period

\begin{tabular}{lccc}
\hline & $\begin{array}{c}\text { Tiotropium, } \\
\mathbf{n = 6 0 8}\end{array}$ & $\begin{array}{c}\text { Placebo, } \\
\mathbf{n = 3 0 5}\end{array}$ & $\mathbf{P}$ \\
\hline Patients with $\geq 1$ exacerbation, \% & 44.1 & 41.0 & 0.395 \\
Number of exacerbations & 0.88 & 0.92 & 0.599 \\
Number of exacerbation days & 16.1 & 16.2 & 0.843 \\
Patients with $\geq 1$ hospitalization, \% & 8.4 & 8.2 & 1.000 \\
Number of hospitalizations & 0.13 & 0.15 & 0.557 \\
Number of hospitalization days & 1.14 & 1.16 & 0.775 \\
Number of courses of oral steroids & 0.58 & 0.55 & 0.599 \\
Number of courses of antibiotics & 1.02 & 1.00 & 0.756 \\
\hline
\end{tabular}

Expressed as events per patient-year, unless otherwise indicated

placebo- or ipratropium-controlled trials $(9,10)$. Swanney et al (21) showed that $\mathrm{FEV}_{6}$ is more reproducible than FVC and may be more relevant in a standard clinic setting. Unfortunately, the $130 \mathrm{~mL}$ improvement in $\mathrm{FEV}_{6}$ cannot be compared with other tiotropium studies, because this is the first time that it has been assessed in a clinical trial with tiotropium and the measurement was only performed at qualified sites as a pilot assessment.

The use of rescue medication provides an indication of the degree of breathlessness experienced by the patient. In the current study, rescue medication use was significantly reduced in the tiotropium group compared with the placebo group. By improving lung function, tiotropium relieves breathlessness. In other studies, tiotropium consistently reduced shortness of breath as measured by the improvement in the transition dyspnea score and decreased use of rescue medication compared with placebo, as demonstrated Brusasco et al (11) and Vincken et al (10).

As with dyspnea, HRQL was better at the end of the oneyear trial, with statistically significant improvements in the SGRQ total score as seen by the improvements in the symptoms and impacts domains. The difference between the treatment groups was slightly less than that observed in previous placebo- and ipratropium-controlled studies (3.7 and 3.3 units, respectively) $(9,10)$. The difference in SGRQ scores might have been larger if there had been fewer drop outs of sicker patients in the placebo group. However, greater than one-half of the tiotropium patients had a clinically meaningful improvement in the SGRQ total score. This is an important, validated subjective improvement that is comparable with results from other tiotropium studies (9). The large improvement in the placebo group is certainly more than would be expected. Perhaps this is explained by the halo effect of being in a study with additional monitoring by the clinic staff, enhanced compliance with their concomitant medication (LABA plus inhaled corticosteroids) and, potentially, the poorer responders dropping out. The clinically significant improvement in the SGRQ total score for smokers compared with the ex-smokers is consistent with greater improvement in lung function in smokers.

The observed lack of a significant difference between treatment groups in exacerbation parameters is in direct contrast to the results from the Spiriva (Boehringer Ingelheim Canada) tiotropium clinical trial program to date $(9-11,13,14)$. There are a number of potential explanations for this finding. The 
trial was not powered to detect a reduction in exacerbations. In addition, an inclusion criterion was amended to permit patients who were less likely to exacerbate to enter the trial (ie, those patients who had only experienced one COPD exacerbation in the past two years rather than those who had experienced a COPD exacerbation in the past 12 months). Had we realized during enrolment what was recently reported by FitzGerald et al (22) that $46.9 \%$ of Canadian patients with moderate to severe COPD might not have an exacerbation during one year, we would not have allowed the change to the inclusion criteria. Finally, commercial tiotropium became available on the market during the study. This may have contributed to the observed higher discontinuation rate in the placebo group $(12.5 \%)$ compared with the tiotropium group (7.4\%) early on in the study (ie, by day 50 ) and may have resulted in a selection bias. Because patients in the tiotropium group remained in the trial for a longer duration than the patients in the placebo group, they may have experienced more respiratory events. Adjusting for the length of exposure diminished the apparent difference between the two treatment arms and is indicative of nonrandom discontinuation influencing the results.

The low exacerbation and hospitalization rates in the placebo group in the present study may reflect, in part, participation in a self-management plan, an increasingly popular treatment strategy in Canada with proven efficacy in reducing the utilization of health care services (23).

Problems associated with differential discontinuation rates between the active and placebo groups in major COPD trials have been discussed by Decramer et al (24). They concluded that premature discontinuation is not completely random, with sicker patients discontinuing earlier than less sick patients, thereby enriching the remaining study group with healthier patients. In the current study, a higher percentage of patients in the 'drop out population' had a history of cardiac and respiratory disorders, in association with a higher use of both cardiac and respiratory medications at baseline. Additionally, the drop out population had more severe COPD at baseline, as assessed by smoking history, lung function, oxygen use and respiratory medications compared with patients who completed the trial, which may reflect a signal toward selection bias. Given the higher drop out rate in the placebo group, the unintentional enrichment of the healthy patients in this group may, in part, explain the lack of a significant difference between the two treatment groups in terms of exacerbations. In addition, Calverley et al (25) found that patients withdrawing from their study's placebo group had a more rapid decline in $\mathrm{FEV}_{1}$ and more exacerbations than the active group. Perhaps if the current placebo group had been followed after study withdrawal, it may have been determined that they too had exacerbations after they dropped out of the study. However, withdrawn patients were not systematically followed up after they dropped out. Therefore, the poststudy exacerbation status was not available for comparison with the patients who remained in the study. This may have permitted an evaluation of any imbalances following premature discontinuation.

The mortality rate in the current placebo group was much lower $(0.7 \%$ per year $)$ than in the placebo or ipratropium control arms in the pivotal one-year tiotropium studies $(1.9 \%$ and $1.7 \%)(9,10)$. As with the issue regarding exacerbations, this large difference probably reflects the early drop out of sicker patients and the fact that the remaining patients in the placebo group had better-controlled disease. The 2.1\% mortality rate for the tiotropium group was comparable with that observed in other one-year studies of patients with moderate to severe COPD (2.0\% to $3.5 \%$ ) (26), and it was comparable to the rate in other tiotropium studies $(1.3 \%$ to $2.5 \%)(9,10,14)$.

\section{SUMMARY AND CONCLUSION}

Compared with the placebo group, tiotropium improved lung function in patients with moderate to severe COPD. There was a treatment response as assessed by $\mathrm{FEV}_{1}$ in both smokers and ex-smokers. The improvements in HRQL and the decreased use of rescue medication support lung function outcomes. The lack of a significant difference in exacerbation rates between the treatment groups cannot be completely explained, especially given positive data in other published tiotropium studies. Tiotropium is considered to be safe and effective in the treatment of patients with moderate to severe COPD even when patients are allowed other concomitant pharmacotherapies.

ACKNOWLEDGEMENTS: This study was funded by Boehringer Ingelheim Canada Ltd and Pfizer Canada.

ETHICS: The study was approved by either local institutional ethics or a centralized ethics board. Participants in the present study gave written, informed consent.

CONFLICTS OF INTEREST: Drs Chan, Maltais and Ford have been members of advisory boards for a number of pharmaceutical companies, including the sponsors of this trial. They are also members of Speakers Bureaux for these companies. Chris Sigouin of the University of Toronto and the founder of Numbers Now Inc performed the statistical analyses for this study. Jennifer Haddon is an employee of Boehringer Ingelheim.

SAFE INVESTIGATORS: John C Acres (Nova Scotia), Didar Ahmad (Ontario), Ronald Akhras (Quebec), Michael Alexander (Ontario), Ross C Anderton (British Columbia), John Anthony (Ontario), Allan Bailey (Saskatchewan), Aras Balsys (Ontario), Meyer S Balter (Ontario), Spencer Barclay (Nova Scotia), John Bartlett (Ontario), Kenneth Bayly (Saskatchewan), Paul Begin (Quebec), Steven Bencze (Ontario), Birubi Biman (Ontario), Harry Birman (Ontario), Graham Bishop (Newfoundland), Stephen P Blackie (British Columbia), Jaques Bouchard (Quebec), Joseph F Braidy (Quebec), Andrew Braude (Ontario), Sarah Lynn Broder (British Columbia), Dieter Bruckschwaiger (Ontario), Maria Bukowskyj (Ontario), Kenneth Buttoo (Ontario), Amarjit Cheema (Ontario), Joseph (Sin Ming) Chien (Ontario), Thomas P Connolly (British Columbia), Terrance Cooligan (Ontario), Richard Alan Dabrusin (Quebec), Robert Dales (Ontario), Dan Dattani (Saskatchewan), Anna Day (Ontario), Anthony Dowell (Quebec), Gordon Dyck (Manitoba), Frank Ervin (British Columbia), Alan Faiers (Ontario), Didier Fay (Quebec), Richard R Feige (British Columbia), Tharwat A Fera (British Columbia), Stephen Field (Alberta), Serge Filion (Quebec), Sandy Finkelstein (Ontario), John Mark Fitzgerald (British Columbia), Gordon T Ford (Alberta), Monique I S Forse (Ontario), George Fox (Newfoundland), Kristen Fraser (Alberta), Ian Fraser (Ontario), Michel A Gagnon (Quebec), Serge Goulet (Quebec), Kempe Gowda (Saskatchewan), Ron Grossman (Ontario), Cindy Hamielec (Ontario), Frederick Hargreave (Ontario), Randolph Hart (Newfoundland), Kay Ho (British Columbia), Richard Hodder (Ontario), Lawrence A Homik (Manitoba), Jeannette Janzen (Quebec), David Kanawaty (Ontario), 
Alan Kaplan (Ontario), Manon Labreque (Quebec), Andy Shu Cheong Lam (Ontario), Pierre Larivee (Quebec), Michel Laviollette (Quebec), Robert Luton (Ontario), Robin Mcfadden (Ontario), Allan P Mclellan (Ontario), Sanjay Mehta (Ontario), Michael Meunier (Quebec), Sheldon Mintz (Ontario), Arun Nayer (Saskatchewan), Dennis O'keefe (Newfoundland), William O'mahoney (Ontario), Michael O'mahoney (Ontario), Bruno Paradis (Quebec), Piyush Patel (Ontario), Leonard Peress (Ontario), Serge Puksa (Ontario), Winston D Rajkumar (Ontario), Warren P Ramesh (Alberta), Julian Raphael (Alberta), Donald Rhodes (Ontario), David Ross (Ontario), Michel Y Rouleau (Quebec), David Ian Small (Quebec), Mohuniall Soowamber (Quebec), Ron Starra (Quebec), David Stubbing (Ontario), Guy Tellier (Quebec), Peter Thomas (Ontario), Frances Tung (Ontario), Richard Tytus (Ontario), John J Vlasschaert (Ontario), Michael Wiegel (Alberta), Pearce Wilcox (British Columbia), David Williams (British Columbia), William Yang (Ontario), Ernest L York (Alberta), Noe Zamel (Ontario).

\section{REFERENCES}

1. Global strategy for the diagnosis, management, and prevention of chronic obstructive pulmonary disease. Updated 2007. National Heart, Lung, and Blood Institute and World Health Organization Global Initiative for Chronic Obstructive Lung Disease (GOLD), 2007. <www.goldcopd.com> (Version current at October 4, 2007).

2. Statistics Canada. Death by selected grouped cases, sex and geography - Canada. <www.statscan.ca/english/freepub/84F0209XIE/ 2003000/t001_en.pdf> (Version current at July 18, 2007).

3. Lopez AD, Murray CC. The global burden of disease, 1990-2020. Nat Med 1998;4:1241-3.

4. Auerbach O, Hammond EC, Garfinkel L, Benante C. Relation of smoking and age to emphysema. Whole-lung section study. N Engl J Med 1972;286:853-7.

5. Burrows B, Knudson RJ, Cline MG, Lebowitz MD. Quantitative relationships between cigarette smoking and ventilatory function. Am Rev Respir Dis 1977;115:195-205.

6. Anthonisen NR, Connett JE, Kiley JP, et al. Effects of smoking intervention and the use of an inhaled anticholinergic

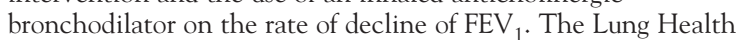
Study. JAMA 1994;272:1497-505.

7. Chaudhuri R, Livingston E, McMahon AD, Thomson L, Borland W, Thomson NC. Cigarette smoking impairs the therapeutic response to oral corticosteroids in chronic asthma. Am J Respir Crit Care Med 2003;168:1308-11.

8. Anthonisen NR, Lindgren PG, Tashkin DP, Kanner RE, Scanlon PD, Connett JE. Bronchodilator response in the lung health study over 11 yrs. Eur Respir J 2005;26:45-51.

9. Casaburi R, Mahler DA, Jones PW, et al. A long-term evaluation of once-daily inhaled tiotropium in chronic obstructive pulmonary disease. Eur Respir J 2002;19:217-24.

10. Vincken W, van Noord JA, Greefhorst AP, et al; Dutch/Belgian Tiotropium Study Group. Improved health outcomes in patients with COPD during 1 yr's treatment with tiotropium. Eur Respir J 2002;19:209-16.
11. Brusasco V, Hodder R, Miravitlles M, Korducki L, Towse L, Kesten S. Health outcomes following treatment for six months with once daily tiotropium compared with twice daily salmeterol in patients with COPD. Thorax 2003;58:399-404. (Erratum in 2005;60:105).

12. Donohue JF, Van Noord JA, Bateman ED, et al. A 6-month, placebo-controlled study comparing lung function and health status changes in COPD patients treated with tiotropium or salmeterol. Chest 2002;122:47-55.

13. Niewoehner DE, Rice K, Cote C, et al. Prevention of exacerbations of chronic obstructive pulmonary disease with tiotropium, a once-daily inhaled anticholinergic bronchodilator: A randomized trial. Ann Intern Med 2005;143:317-26.

14. Dusser D, Bravo ML, Iacono P. The effect of tiotropium on exacerbations and airflow in patients with COPD. Eur Respir J 2006;27:547-55. (Erratum in 2006;27:1076).

15. O'Donnell DE, Aaron S, Bourbeau J, et al. Canadian Thoracic Society recommendations for management of chronic obstructive pulmonary disease - 2007 Update. Can Respir J 2007;14(Suppl B):5B-32B.

16. American Thoracic Society/European Respiratory Society Task Force. Standards for the diagnosis and management of patients with COPD, 2005. <www.thoracic.org/sections/copd/> (Version current at October 7, 2007).

17. Morris JF, Koski A, Temple WP, Claremont A, Thomas DR. Fifteen-year interval spirometric evaluation of the Oregon predictive equations. Chest 1988;93:123-7.

18. American Thoracic Society. Standardization of spirometry: 1994 update. Am J Respir Crit Care Med 1995;152:1107-36.

19. Jones PW, Quirk FH, Baveystock CM, Littlejohns P. A selfcomplete measure of health status for chronic airflow limitation. The St George's Respiratory Questionnaire. Am Rev Respir Dis 1992;145:1321-7.

20. Calverley MA, Burge PS, Spencer S, Anderson JA, Jones PW. Bronchodilator reversibility testing in chronic obstructive pulmonary disease. Thorax 2003;58:659-64.

21. Swanney MP, Jensen RL, Crichton DA, Beckert LE, Cardno LA, Crapo RO. FEV(6) is an acceptable surrogate for FVC in the spirometric diagnosis of airway obstruction and restriction. Am J Respir Crit Care Med 2000;162:917-9.

22. FitzGerald JM, Haddon JM, Bradly-Kennedy C, Kuramoto L, Ford GT. Resource use study in COPD (RUSIC): A prospective study to quantify the effects of COPD exacerbations on health care resource use among COPD patients. Can Respir J 2007; $14: 145-52$.

23. Bourbeau J, Julien M, Maltais F, et al. Reduction of hospital utilization in patients with chronic obstructive pulmonary disease: A disease-specific self-management intervention. Arch Intern Med 2003;163:585-91.

24. Decramer M, Gosselink R, Rutten-Van Mölken M, et al. Assessment of progression of COPD: Report of a workshop held in Leuven, 11-12 March 2004. Thorax 2005;60:335-42.

25. Calverley PM, Spencer S, Willits L, Burge PS, Jones PW. Withdrawal from treatment as an outcome in the ISOLDE study of COPD. Chest 2003;124:1350-6.

26. Sin DD, Wu L, Anderson JA, et al. Inhaled corticosteroids and mortality in chronic obstructive pulmonary disease. Thorax 2005;60:992-7. 


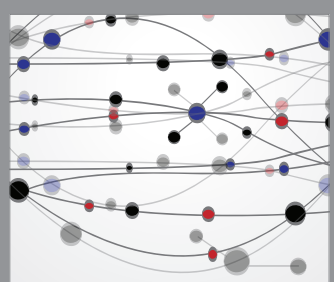

The Scientific World Journal
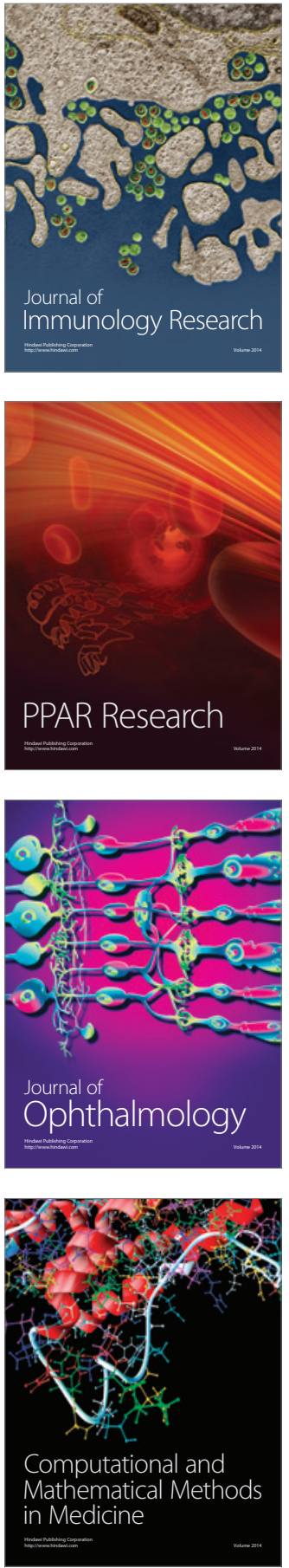

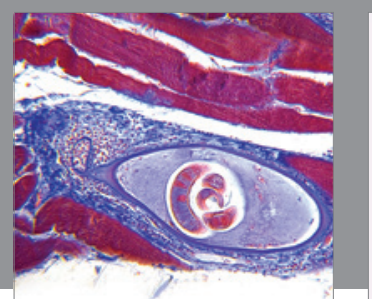

Gastroenterology Research and Practice

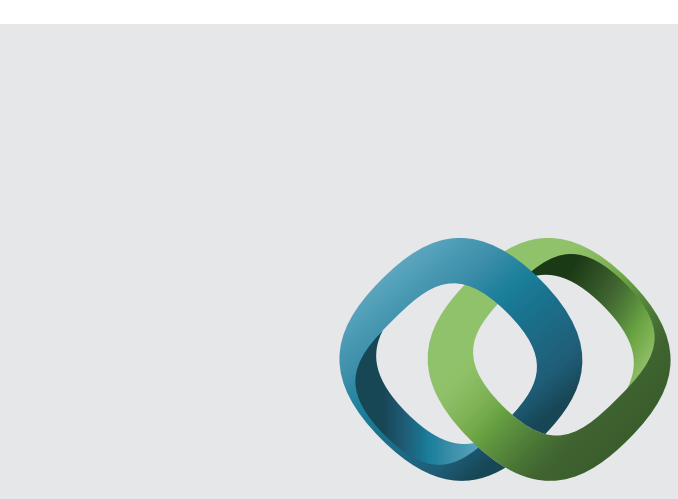

\section{Hindawi}

Submit your manuscripts at

http://www.hindawi.com
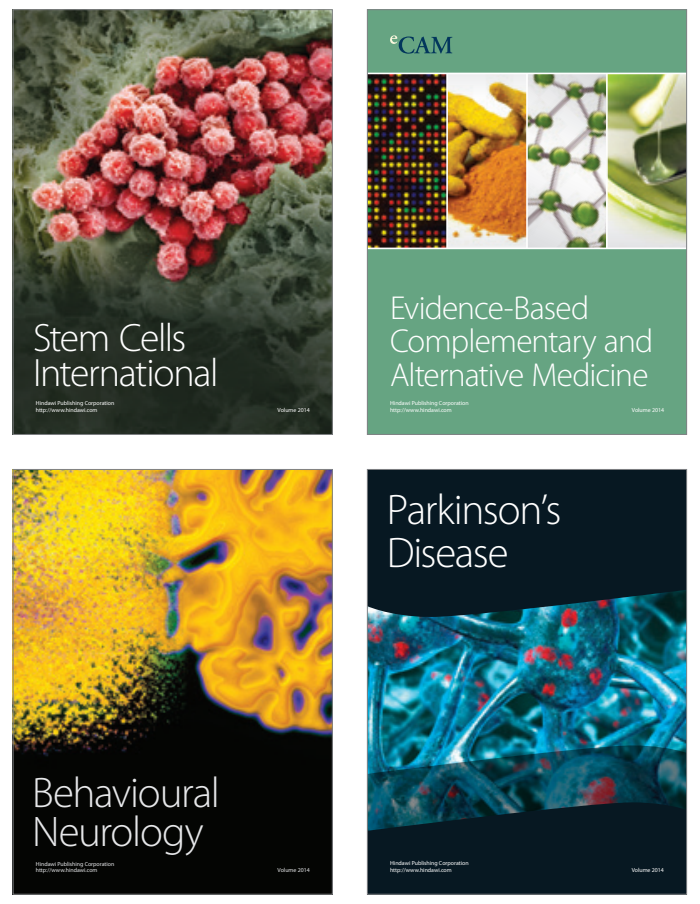
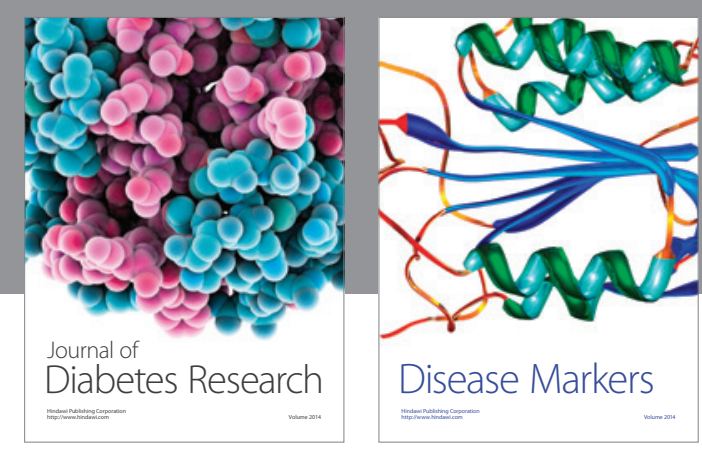

Disease Markers
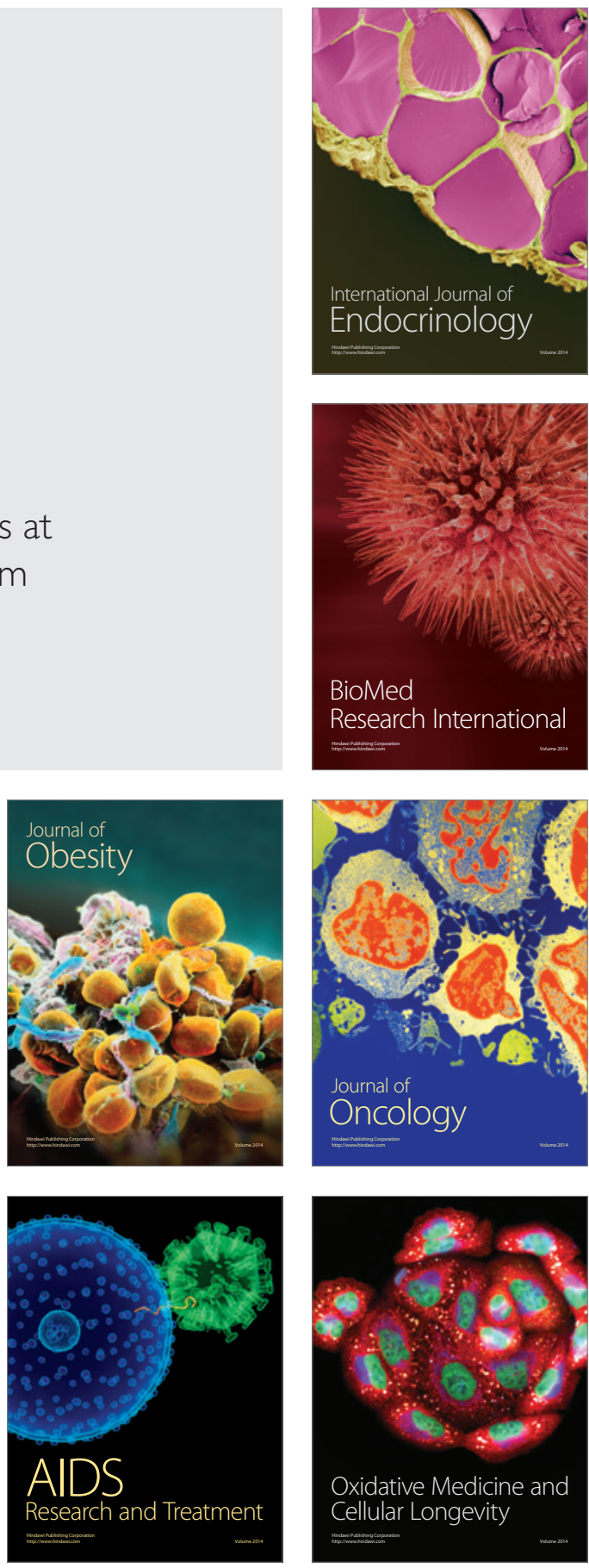